\title{
AN INTRODUCTION TO THE IMPACT \\ OF BAUHAUS MULTI-DISCIPLINARY PEDAGOGICAL MODEL ON ITS FEMALE STUDENTS
}

\author{
Marisa Vadillo Rodríguez \\ Universidad de Sevilla. Dpto. de Dibujo
}

\section{Abstract}

The German school of the Bauhaus (1919-1933) had turned, in only fourteen years, into a pedagogic, investigative and artistic model. Their new improved pedagogical example is defined by the way in which their different academic programs were based on the multidisciplinary of the classical arts, which until then had been separately classified in painting, sculpture and architecture. The artists that were educated in the Bauhaus changed the history of the modern design, imposing an educational model that opened the doors to the kind of multidisciplinary research that nowadays we still support in contemporary art centres. Accordingly, one of the Bauhaus' most affected sectors by the training and multidisciplinary research was the group of female students who were educated in this famous centre, being known today as artists of recognized international prestige.

Keywords: BAUHAUS (GERMAN SCHOOL); WOMEN IN ARTS; WOMEN IN DESIGN; MULTIDISCIPLINARY RESEARCH

\footnotetext{
Vadillo Rodríguez, Marisa. 2020. "An introduction to the impact of Bauhaus multi-disciplinary pedagogical model on its female students". AusArt 8 (1): 259-270. DOI: 10.1387/ausart.21527
}

\section{AUSART}




\section{INTRODUCTION}

The Bauhaus (1919-1933) is probably one of the best art and design schools of the 20th century. Despite its relatively small student body, hosting only about a thousand students, its contributions made it a top reference in creation and artistic pedagogy of the last century. Of its greatest merit was the design of unpublished objects to generate forms and solutions that even today, continue to be imitated. The widespread quality of its students may have been, as prestigious designer and alumni Margaret Leischner (1908-1970) stated, due to the fact that the Bauhaus demanded them "never to be satisfied with the first solution" (Leischner 1968).

In fact, if we reflect upon the impact of Bauhaus products (furniture, textiles such as rugs and tapestries, kitchen objects, ceramics or mural paintings, etc.) we find that they have something in common: they were all created specifically for the single family home. Thus, with these social purposes in mind, the Bauhaus designers reformed the objects of this domestic space, incorporating new ergonomic, practical and aesthetic needs in the development of the products, using materials that were better suited to the changing everyday needs. Without a doubt, the model that they created could only be developed with the use of a creative and multi-disciplinary professional concept, applied to both the object and the space.

The incorporation of Hannes Meyer (1889-1954) in the management of the Bauhaus in 1928 brought with it the reorganization of all of the workshops that had been previously been taught in the school. The new director created departments that combined different courses, in a clearly multi-disciplinary conceptualization that valued the conception of the object as the result of multiple knowledge servicing creation with a social purpose. Thus, the Advertising Department would include the former Printing and Advertising Workshop, along with the Sculpture workshop and a novel course on Photography, which would be added in 1929. The Textiles Department would include Fabric and Tapestries with the addition of Dyeing. The Finishings and Decoration (or Interior Design) Department included the Metals, Carpentry (Furniture) and Mural Painting workshops. It was during this new phase when, for the first time, the Architecture Department was included in 1928 (nine years after the creation of the Bauhaus and only four years prior to its dissolution). It included some courses on the study of project administration, blueprint drawings and materials, among others. Later, in 1930, with the management changes that led to the replacement of Meyer by Mies van der Rohe (1886-1969), there would be 
a new organization of all of the departments related to architecture. Thus, the Construction and Finishings Department was created which would combine all of the previous workshops of the former Finishings and Decoration Department, to which the Architecture Department would be added.

The objective of this study is to highlight the revolution that took place with the inclusion of a crosscutting teaching approach in the Bauhaus educational programs. Specifically, it focuses on the impact of this approach on the school's female students. These women, who tended to carry out their studies in the Textile Department after completing the Preliminary Course, were thus able to enjoy a more plural and all-encompassing education that offered them a modern conceptualization of the design and creation trade, of modern everyday objects and of the social; beyond merely acquiring novel textile techniques. Thanks to the distinct study programs, Bauhaus courses were not encapsulated, making these designers and artists the first generation to enjoy a professional education in modern design. In the extensive international bibliography on the school, numerous publications appear, including the monographies by Rainer K. Wick (2000) and Anja Baumhoff (2001), occasionally addressing their general pedagogy or the impact of the gender policy. However, the study that we are concerned with highlights the specific link between the applied multi-disciplinary pedagogy and the professional development of Bauhaus' female students. Thus, it offers a novel view of its famous pedagogical approach based on a social, artistic and multi-disciplinary conceptualization that ensured a permeable education allowing women to design the society of their times.

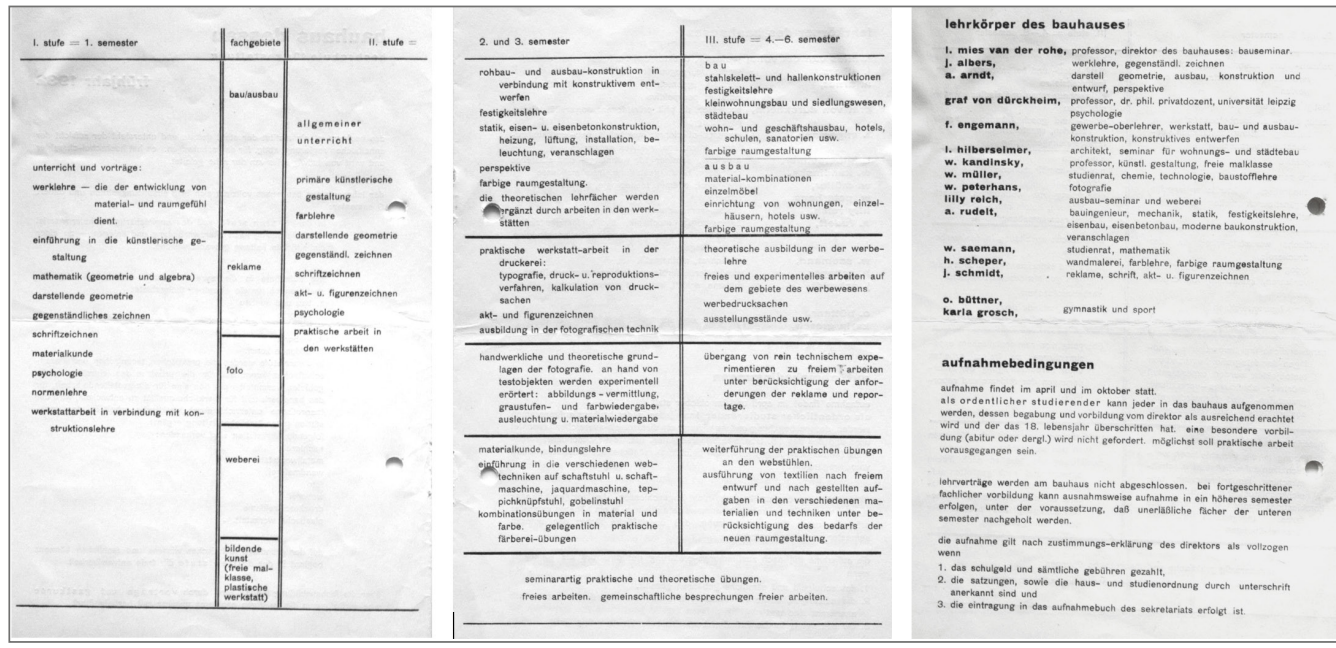

Figure 1: Bauhaus Archiv Berlin (BHA). Otti Berger. Folder 17. Inv. Nº64/565. Studies Diploma. 
We cannot fail to consider that the presence of women in the Bauhaus was a fundamental phenomenon for its production and prestige, both during the initial Weimar phase and during the subsequent periods in Dessau and Berlin. Perhaps, these women would benefit the most from the multi-disciplinary conceptualization of the Bauhaus pedagogy given the prejudices that were often suffered in educational politics. Although in most cases, the women were oriented towards the Textiles Department, but even this area permitted them to explore other distinct areas, such as furnishings. Furthermore, many of the women participated greatly in the other sections, as 'visiting students', thereby benefiting from a plural education that would change the history of art and design.

\section{FABRIC DEPARTMENT}

One of the most interesting perspectives for the designers training in Dessau was that the theoretic ideal of the Bauhaus continued to be architecture and thus, the Fabric Department students were similarly affected, with their products clearly evolving from ancient tapestries to modern elements incorporated in the home and living space. The global and domestic space of application of all textiles produced in the workshop, either through the design of furnishings with their application in objects or through products such as tapestries and rugs -which architecture students believed to have the function of 'coating'-. This idea of coating strongly challenged the beliefs of the weavers, who considered that these rug pieces should respond conceptually to the so-called "weaving of complexes", as the very author described in a text that was kept in the Stiftung Bauhaus from Dessau, without page number, under inventory number 'I 15590'. That is, an object that should respond to a flexible and esthetic function as well as being functional, thereby responding to the two fundamental principles of the designed object: form and function. This was the result of a clearly multi-disciplinary conceptualization of the woven object.

Similarly, one of the typical practices of the Fabric Department, from its onset in the Weimar headquarters, and which was strengthened in Dessau, was the profound material experimentation, thanks to a multi-disciplinary pedagogical conception. In the new headquarters, this desire to seek out new raw materials led to the creation of unprecedented textiles to be applied to the most demanding uses of the industry, offering historic results. The weavers therefore developed an interest in creating structural textiles in which practical application took 
precedence over the decorative, thus, the study of the use of artificial materials (such as cellophane) was incorporated in the textile practice. These studies of the textile designers were functional discoveries, given that they allowed for the viewing and provision of new textile qualities having a clear social impact. Of these, we find those with the capacity to absorb sound through cellophane, or the development of what would become a star product, the so-called 'metal wire' for the covering of tubular steel chairs made of twisted and paraffin-embedded cotton fibers. They also designed carpeting that is still sold today by the brand "Vorwerk \& Co.", created by the historic Bauhaus designers such as Gunta Stölzl (1897-1983), Gertrud Arndt (1903-2000), Kitty Fischer (18971973), Monica Bella-Ullman (or, later Broner, 1905-1993) and Grete Reichardt (1907-1984).

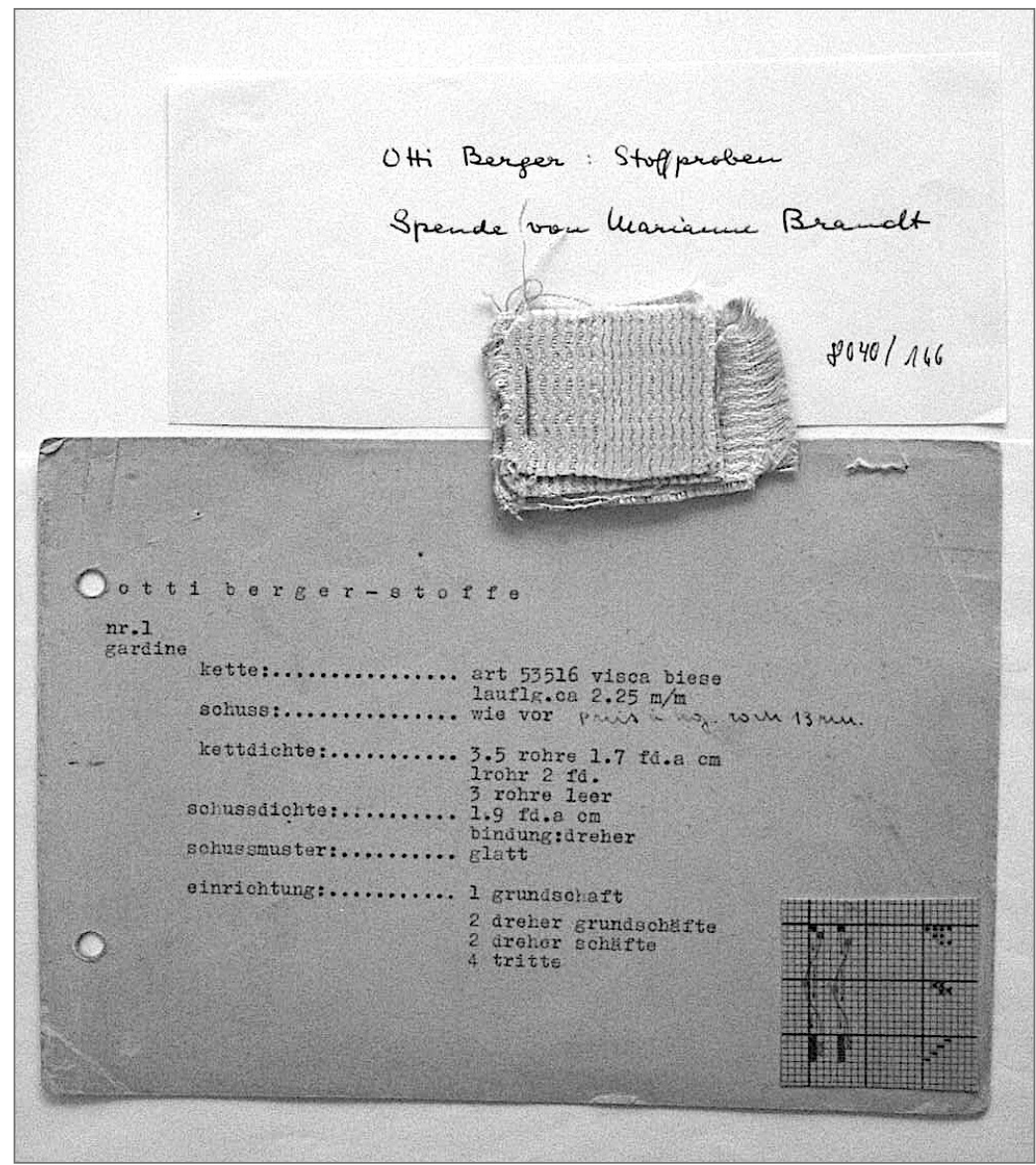

Figure 2: Bauhaus Archiv Berlin (BHA). Otti Berger. Folder 5. Inv. № 8040/166. 
Luckily, the fascinating artistic talents that attended this workshop rapidly came to fruition. An excellent example of this is the case of Otti Berger (18981944) who was in Bauhaus from 1927 until October of 1930, the year in which he received her diploma from the school. In the Dessau headquarters, she developed a valuable textile and pedagogical work in this workshop which she directed between October of 1931 and February of 1932, with her study plan being preserved, without date, in inventory number 8040/150, in the fourth folder of the Bauhaus Archiv. Subsequently, she would become assistant of the director of the workshop. Lilly Reich, who was not a weaver.

Her quality as a designer would lead her to patent textiles and to collaborate regularly with the industry in a sweeping trajectory, working with companies where she would develop her work as a fabric designer. For example, she made curtain textiles for Fischer \& Hoffmannn in Zwickau and from May to October of 1931, for Websky, Hartmann \& Yiesen in the design of tablecloths and linens. She also worked for the company Ploeg, in which she was the sole female designer. Unfortunately, all of her achievements in the area of design and her great artistic quality had to be demonstrated during a limited period of time, given that, like other Jewish artists of the Bauhaus- she was deported and murdered, possible following her 1942 transport to a concentration camp. In her personal documentation, one can perceive the distressing situation existing with the national-socialist administration to whom she requested to continue to act as an artisan, in letters that by 1934 were received from the official documentation of the National Chamber of German Artisans, with negative responses that would put an end to her work. All of this would not prevent Berger's rapid success. In fact, one of the fabrics that she created in 1930 was exhibited in 1938 in New York's famed Museum of Modern Art.

\section{DEPARTMENT OF FINISHINGS AND DECORATION. ITS TRANSFORMATION INTO THE DEPARTMENT OF CONSTRUCTION AND FINISHINGS}

The former Carpentry Workshop had been directed in Dessau by the fantastic designer Marcel Breuer from 1925 to 1928, a discipline that was incorporated in the multi-disciplinary Department of Finishings and Decoration when cre- 
ating this educational approach in 1929 under the leadership of Josef Albers. Finally, in 1930, it would be included in the Department of Construction and Finishings with Alfred Arndt.

On the other hand, during the school's headquarters in Dessau, the production of the Mural Painting Workshop focused on three areas: mural painting in architectural interiors, the design of painted wallpapers (as a novelty) and the finishing of wood products, especially furnishings and toys. The addition of painted papers to this workshop was a clear success, especially when we consider that they worked with prototypes made by students from a school (and not from a factory or a commercial enterprise) although at the Bauhaus, trials with products took place consistently.

Thus, the famous painted wallpapers created in the Bauhaus were revolutionized by an aspect that was fundamental in the overall pedagogy of the school: the material. This multi-disciplinary research allowed, as Scheper observed, that "in 1930 [it] was the first in Germany to offer gravure-printed wallpapers using oil-based colours and therefore being not only durable, but also waterproof" (Bauhaus Archiv 2005). In fact, one could not ask for more: washable painted wallpaper that was a modern product of great esthetic quality, low cost, functional and hygienic. With this wallpaper, the Bauhaus once again managed to achieve a social ideal through the creation of a domestic product.

Another of the most outstanding students trained in these interdisciplinary departments was Wera Meyer-Waldeck (1906-1964) who furthered her training in this new department, in which architecture played a significant role. She attended the Furnishings Workshop during her sixth semester, between 1929 and 1930, collaborating with an architecture office with the Meyer's project known as Bundesschule des allgemeinen deutschen gewerkschaftsbundes, in Bernau. Upon returning to her training in the Department of Finishings and Decoration (furnishings) in 1931 she began in architecture with Hilberseimer, Engemann and Dürckheim. She also studied in the area of mural painting with Scheper in 1932. To obtain her diploma from the Bau-

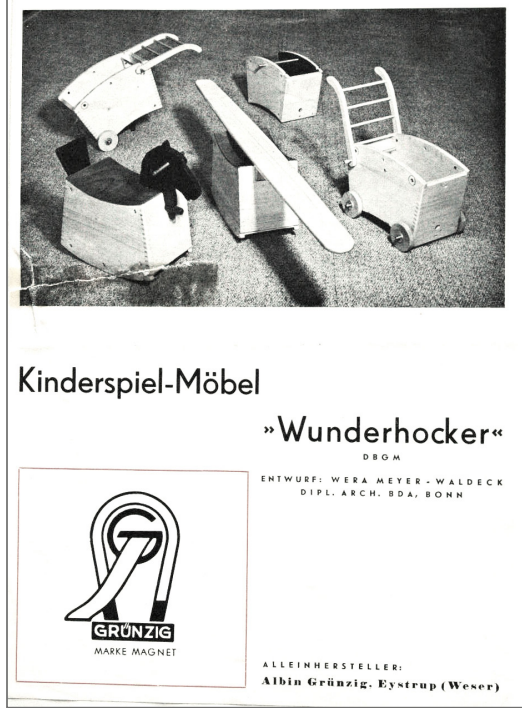

Figure 3: Bauhaus Archiv Berlin (BHA). Wera Meyer-Waldeck. Folder 1. Inv. N¹1465/1. 
haus, she worked on a prototype for a primary school and children's hospital for sixty children, as a project of the Foundation-Junkers in Dessau.

We cannot forget, among many others, the contributions of Annemarie Mauck (1906-1996) who entered Dessau in 1929. She participated in this workshop during the summer semester of 1930 in the Department of Finishings and Decoration, in the area of furnishings. From here she would go on to the Department of Construction and Finishings in 1930 where she would remain until 1932, given that she continued her training in the Berlin headquarters of the school. Her skill in the design of furniture and other objects, can be appreciated in their sketches, such as that of a sofa bed (held in folder 1 of the Bauhaus Archiv under inventory number 1997/26.1), a doll house (Inv. No. 1997/26.4-6) or other household objects such as vases. Her skill as an architect was demonstrated subsequently in numerous projects.

\section{ADVERTISING DEPARTMENT}

The constant presence of graphic design in the Bauhaus took the form of a modern workshop on Typography and Advertising in the Dessau headquarters under the direction of Herbert Bayer who led the same from 1925 until 1928. Later, he was substituted by Joost Schmidt from 1928 to 1932. Meyer appointed him director of the "Typography, advertising and organization of exhibitions" laboratory, a space that closed when the school was moved to Berlin.

In the specific case of photography, and following the important work carried out by Lucia Moholy (1894-1989) with her production without the existence of a formal course, the arrival of the prestigious Walter Peterhans to the Bauhaus is of special significance. He was followed by one of the most important photographers to be trained at the school, Grete Stern (1904-1999), who had previously been his student during 1927 and 1928 in his private studio in Berlin. Precisely this period in the training of Stern at Bauhaus coincided with the modern photography studio that she set up with Ellen Auerbach (1906-2004), known as "ringl+pit", where they created all sorts of images, including those for advertising. From this laboratory, a documentary was created, produced and directed by Mandelbaum and entitled Ringl and Pit. It was edited by Geovision in 1995. Graeve (2003) stated that "Grete Stern, who already had a degree in graphic arts and until 1932 attended courses at Bauhaus, was especially interested in 
the experimental photography of objects; to her we must attribute, above all, the formal arrangement of images, in the esthetic line of the photography materials of the new objectivity".

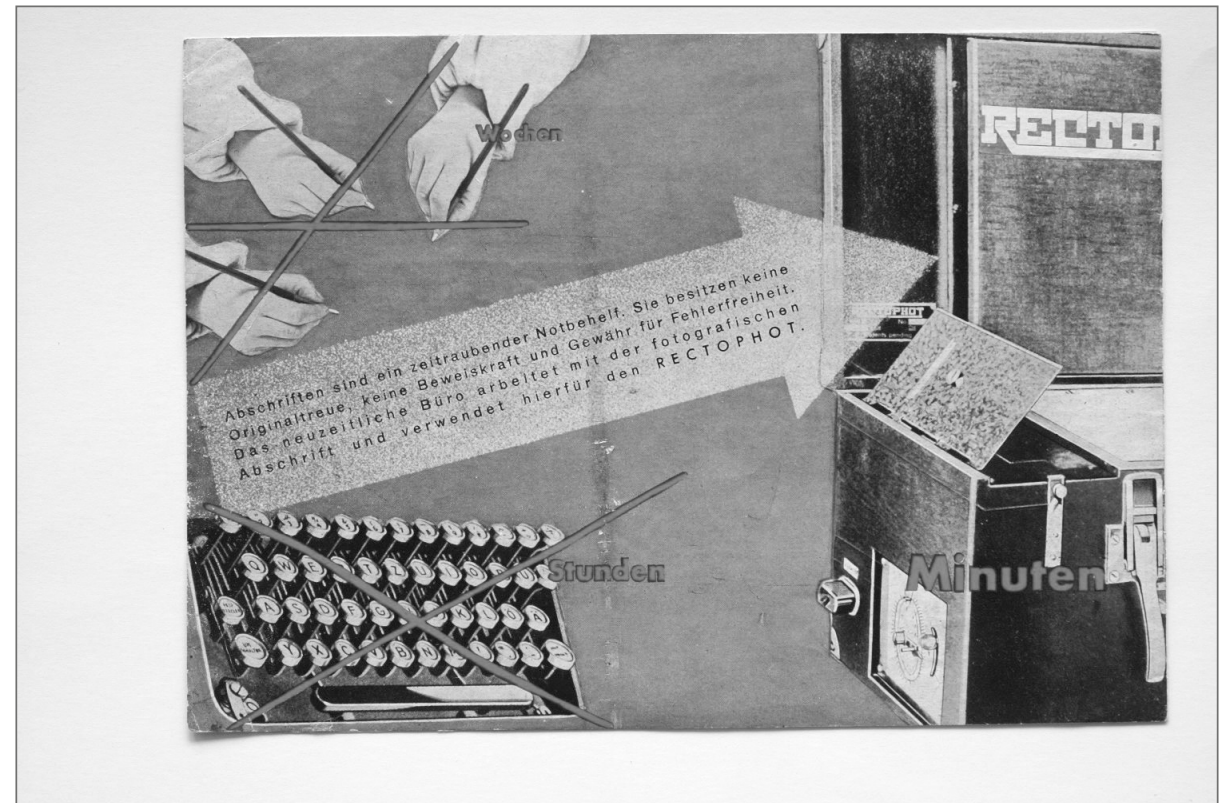

Figure 4: Bauhaus Archiv Berlin (BHA), Irene Hoffman. Folder 25. Inv. № 6389.

Another of its most important students of this period was Irene Hoffmann (19031971) who studied at the Bauhaus from 1929 until 1932. Like others, in 1937 she was forced to emigrate to the US. She was recognized as an excellent photographer with a production that was linked to advertising and typography, both of which she studied in the class taught by Joost Schmidt. As a student, Hoffmann used photography mainly as an advertising element. In this sense, she made two interesting pieces for Schmidt in which "they had to repeatedly take on photographic montages. In this work from 1930, Irene Hoffmann contrasted elements of the political and societal fields with sports and leisure" (cited in Droste 1998). In both proposals, the author played with the manipulation of scale and different textures in order to obtain photo-collages of great impact.

An original advertising poster made in collage announcing a school product is of special note. In fact, the composition is a clear example of the fusion of typography and photography that Bauhaus promoted, as valued by teachers 
such as Moholy-Nagy in a clearly multi-disciplinary conception of the visual and graphic communication. The protagonist is a girl crying over a flat blue background; out of her mouth, the product's review comes out, in the form of a shout, forming a diagonal that establishes the visual path from the initial point of attention, the child, to the fundamental brand (Nivea) which appears in the upper half.

Another noteworthy example, from the dozens of authors of international renown who trained in this area at Bauhaus, is Elsa Thielmann (1910-1981). According to a copy of her marriage certificate which is held in the Bauhaus Archiv in Berlin (BHA, Inv. No. 9504/33), her maiden name was Elsa Käthe Wilhelmine Franke. Here we find an interesting document dated the $4^{\text {th }}$ of March of 1947 in Neukölln, which also refers to her as a graphic artist. Thielmann received her diploma from the Bauhaus -number 59-from this workshop with Schmidt during the winter semester of 1929 , as seen in the documentation from folder 3, corresponding to Inv. No. 9504/78, 80-82 of the German archive. She studied at the Bauhaus from 1929 until July $10^{\text {th }}$ of 1931 . Furthermore, she attended the Photography Workshop of Peterhans during the summer semester of 1930. In fact, she would go on to develop an important career, which she began in Berlin in 1931, as a freelance graphic reporter, coming to be known as a great chronicler of this city during World War II. Her regular relationship with the communication and editing media led to her employment as an editorial assistant for the editorial Hoffmann und Campe in Berlin, at the end of the war, as of the $15^{\text {th }}$ of December of 1944.

\section{CONCLUSIONS}

Ultimately, the multi-disciplinary concept of art, architecture, the role of the designer serving society and of the role of industry and pedagogy, was the essence of creation in the Bauhaus. This multi-disciplinary vision permitted the creation of a series of artistic and domestic products that would have a real impact on society, a revolution that continues to be present today in our homes, in our way of life, and in the teaching plans of many contemporary artistic centers. Despite the numerous problems of practical application, the ideal proposed by Gropius in a letter to Ekkart (Adolf Behne) on the $2^{\text {nd }}$ of June of 1920 remains significant. In this letter, he clearly established that "the crux is that today, it is impossible to reform a part of everything, we must put our entire 
life in question: the way of living, childhood education, gymnastics and so on to infinity" (cited in Droste 1998).

In this objective of putting our entire life in question, the women studying at the Bauhaus played a fundamental role. They created their artistic works and expressed their identity as authors using materials as diverse as threads, photographs, clay, metal, wood, etc., to achieve this ideal of functional construction that ruled in the school, until coming to represent almost fifty percent of the student body in some courses. These women of the Bauhaus were perhaps the ones to benefit the most from the center's multi-disciplinary approach. With clear orientations towards the Textile Workshop or the Fabric Department, given the gender policy of the time, it can be seen and verified in specific publications (Vadillo 2010, 2016; Hervás 2015), that all of the pedagogy had a modern, global and multi-disciplinary purpose, considering numerous theoretical, practical and labor-related aspects with regards to the industry. Thus, these women were prepared in a unique way. As former student Lou Scheper-Berkenkamp (1901-1976) clearly stated: "each expected theoretical and practical opportunities in Weimar and the realization of his own, often still vague, conceptions and wishes - opportunities that at that time were only open in that place, the Bauhaus" (cited in Scheper 1985). Thus, a generation of artists and designers arose, having international impact, including top figures who are recognized in numerous international museums and who are indispensable in the world of art and design, as is the case with Anni Albers, Alma Buscher (1899-1944), Marianne Brandt, Wera Meyer Waldeck, Gunta Stölzl and Margaret Leischer, among many others. Without a doubt, it was the multi-disciplinary concept of the creation to serve society, which permitted the generation of a historic educational impact that has yet to be equaled today.

The area of research proposed by this study raises new concerns that will be considered in future publications. One of the most viable and powerful of these relates to the specific work of Bauhaus' female teachers, a research line that we are currently undertaking. This new research area examines how women were intertwined in the school's pedagogy, as well as the teaching field. In this way, we shall demonstrate their level of responsibility in the school's multi-disciplinary conceptualization.

\section{References}

Baumhoff, Anja. 2001. The gendered world of the Bauhaus: The politics of power at the Weimar Republic's Premier Art Institute. 1919-1932. Frankfurt: Peter Lang 
Droste, Magdalena. 1998. Bauhaus 1919-1933. Köln: Taschen

Graeve, Inka. 2003. "Today is tomorrow and yesterday: The photographer Ellen Auerbach". En Ellen Auerbach: La mirada intuitiva: Colección Archiv der Akademie der Künste de Berlin; Exposición organizada y producida por la Fundación "La Caixa". Barcelona: Fundació La Caixa

Hervás y Heras, Josenia. 2015. Las mujeres de la Bauhaus: De lo bidimensional al espacio total. Buenos Aires: Diseño

Leischner, Margaret. 1968. "The Bauhaus a legend?”. Journal of the Royal Society of Arts 116

Mandelbaum, Juan. 1995. Ringl and Pit. Produced by GEOVISION. Vídeo de Vimeo, 59:00. https://vimeo.com/397553978

Rainer, Wick K. 2000. Teaching at the Bauhaus. W ith a text by Gabriele Diana Grawe. Ostfildern-Ruit: Hatje Cantz

Scheper, Lou. 1985. "Retrospective”. En Bauhaus und Bauhäusler: Erinnerungen und Bekenntnisse, herausgegeben von Eckhard Neumann. Köln: DuMont

Scheper, Renate. 2005. "Die Geschichte der Werkstatt für Wandmalerei am Bauhaus" [The history of the wallpainting workshop at the Bauhaus]“. En Farbenfroh! Die Werkstatt für Wandmalerei am Bauhaus [Colourful! The wallpainting workshop at the Bauhaus]. Berlin: Bauhaus-Archiv/Museum für Gestaltung

Vadillo Rodríguez, Marisa. 2010. Otra mirada: Las fotógrafas de la Bauhaus. Sevilla: Universidad de Sevilla

- . 2016. Las diseñadoras de la Bauhaus: Historia de una revolución silenciosa. Córdoba: Cántico

\section{Archives}

Bauhaus Archiv Berlin (BHA). Berger, Otti. Folder 17. Inv. N645/565.

Bauhaus Archiv Berlin (BHA). Berger, Otti. Folder 4. Inv. N 8040/150.

Bauhaus Archiv Berlin (BHA). Berger, Otti. Folder 5. Inv. N 8040/166.

Bauhaus Archiv Berlin (BHA). Hoffman, Irene. Folder 25. Inv. Nº 6389.

Bauhaus Archiv Berlin (BHA). Mauck, Annemarie. Folder 1. Inv. N 1997/26.1.

Bauhaus Archiv Berlin (BHA). Mauck, Annemarie. Folder 1. Inv. N 1997/26.4-6.

Bauhaus Archiv Berlin (BHA). Meyer-Waldeck, Wera. Folder 1. Inv. N¹1465/1.

Bauhaus Archiv Berlin (BHA). Thiemann, Elsa. Folder 2. Inv. N 9504/33.

Bauhaus Archiv Berlin (BHA). Thiemann, Elsa. Folder 3. Inv. N 9504/78, 80-82.

Stiftung Bauhaus Dessau (SBD). Meyer-Bergner, L., Inv. N I 15590.

\footnotetext{
(Artículo recibido: 10-03-20; aceptado: 14-05-20)
} 